\title{
Stable isotopes of carbon and oxygen in modern sediments of carbonate platforms, barrier reefs, atolls and ramps: patterns and implications
}

\author{
EBERHARD GISCHLER ${ }^{1}$, PETER K. SWART ${ }^{2}$ AND ANTHONY J. LOMANDO ${ }^{3}$ \\ ${ }^{1}$ Johann Wolfgang Goethe-Universität, Geowissenschaften, 60325 Frankfurt am Main, Germany \\ ${ }^{2}$ University of Miami, RSMAS-MGG, Miami, Florida 33149, USA \\ ${ }^{3}$ ChevronTexaco, Bahrain Pouch, San Ramon, California 94583, USA
}

\section{ABSTRACT}

Stable isotopes of carbon $\left(\delta^{13} \mathrm{C}\right)$ and oxygen $\left(\delta^{18} \mathrm{O}\right)$ were analyzed in surface and subsurface sediments of modern carbonate platform and barrier reef (Belize), atoll (Maldives) and ramp (Kuwait) settings. The $\delta^{13} \mathrm{C}$ values ranged from -1.6 to $+5.3 \%$ and $\delta^{18} \mathrm{O}$ values from -3.2 to $+2.3 \%$. Among individual particle types, non-skeletal grains such as peloids and ooids exhibit highest values whereas coral fragments display relatively low $\delta^{13} \mathrm{C}$ and $\delta^{18} \mathrm{O}$ values. The highest statistically significant correlations between abundance of carbonate grains, mineralogy and geochemistry occur in the ramp setting, where facies types may be defined using carbon and oxygen isotopic composition. In the platform, barrier and atoll examples, correlations are poor and there are no clear spatial trends in the carbon and oxygen isotopic values of sediments or facies. In locations with comparably high amounts of non-skeletal grains, $\delta^{13} \mathrm{C}$ values correlate with the aragonite content of the samples. The difference between the ramp and other examples is probably a consequence of the continuous depositional energy gradient, which appears to be the major controlling factor of facies distribution in the ramp setting. In the atoll, barrier reef and platform examples, depositional energy gradients are more variable due to higher morphological and environmental variability. The $\delta^{13} \mathrm{C}$ and $\delta^{18} \mathrm{O}$ values of samples from Holocene cores also exhibit high total variability ranging from -1.9 to $-0.5 \%$ in $\delta^{13} \mathrm{C}$ and from -0.2 to $+5.2 \%$ in $\delta^{18} \mathrm{O}$. Strong excursions in $\delta^{13} \mathrm{C}$ and $\delta^{18} \mathrm{O}$ in individual cores are seen near the base where values became 
more negative as a consequence of diagenesis, i.e., the influence of a subaerial exposure horizon. Above the meteorically influenced section, however, variability along individual cores is comparably low $(<1.2 \%)$. The enormous carbon and oxygen isotopic variability observed in modern shallow water carbonates as compared to fossil sections, where $\delta^{13} \mathrm{C}$ is used as stratigraphic marker, is probably a result of as yet poorly defined taphonomic and diagenetic filters, which significantly reduce isotopic variability.

Keywords carbonates, sediment, isotopes, Belize, Kuwait, Maldives

\section{INTRODUCTION}

The ratio of the stable isotopes of carbon, $\left({ }^{13} \mathrm{C}\right.$ and $\left.{ }^{12} \mathrm{C}\right)$, in carbonate sediments and rocks, expressed as $\delta^{13} \mathrm{C}$, is used in paleoceanography as a proxy for changes in production, burial and preservation of organic matter (Broecker, 1982). Carbon isotope records are also used as a proxy for the concentration of atmospheric $\mathrm{CO}_{2}$ through geological time. These records form a significant component of paleoclimate models that are in turn used to predict future global warming. The $\delta^{13} \mathrm{C}$ from bulk rock is also used as a stratigraphic tool (Scholle \& Arthur, 1980; Weissert, 1989), especially in pelagic deposits. During the past decade, the stratigraphic method has also been applied to ancient shallow water carbonate settings of ramps and carbonate platforms (Jenkyns, 1995; Vahrenkamp, 1996; Drzewiecki \& Simo, 1997; Ferreri et al., 1997; Mutti et al., 1997; Grötsch et al., 1998; Wissler et al., 2003; Cozzi et al., 2004). Immenhauser et al. (2002) discussed the large variability in carbon and oxygen isotope values in shallow water carbonates and showed that there is a systematic offset between bank and off-bank isotope data in a Carboniferous example. A possible explanation is the depletion in ${ }^{13} \mathrm{C}$ of carbonate bank waters due to respiration of organic matter, which was demonstrated on the modern Great Bahama Bank by Patterson \& Walter (1994a). Elevated ${ }^{13} \mathrm{C}$ may be observed during high-amplitude transgressions when isotopically depleted bank water mixes with open marine water (Immenhauser et al., 2003). Swart \& Eberli (2005) were able to correlate shallow water bank, slope and basin sections using $\delta^{13} \mathrm{C}$ 
in the Miocene to Holocene of the Bahamas. However, $\delta^{13} \mathrm{C}$ values along their sediment cores did not correlate with the global $\delta^{13} \mathrm{C}$ trends. Apparently, there are problems with the applicability of carbon isotopes as environmental and stratigraphic proxy in shallow water depositional environments. In this study, we show the large variability of carbon and oxygen isotopes in Holocene shallow water carbonate sediments and discuss the significance of our findings with regard to the use of $\delta^{13} \mathrm{C}$ as paleoceanographic and stratigraphic proxy in fossil shallow water settings.

\section{STUDY AREAS}

The Belize-Yucatan carbonate platforms include Glovers Reef, Lighthouse Reef, Turneffe Islands and Banco Chinchorro, which range in size from 200-550 km² (Figure 1). Surfacebreaking reefs surround interior lagoons that are up to $18 \mathrm{~m}$ deep. Lagoonal patch reefs are common with the exception of Turneffe Islands, where interior lagoonal circulation is restricted as a result of dense mangrove growth. Reefal sediments are largely coralgal grainstones whereas lagoonal sediments are dominated by fragments of mollusks, foraminifera and non-skeletal grains (Glovers, Lighthouse, Chinchorro) as well as Halimeda (Turneffe) (Gischler \& Lomando, 1999). Holocene platform lagoon cores usually show an upcore succession of late Pleistocene/early Holocene soil, early Holocene mangrove peat and marine carbonates. Marine carbonate sediments often show indications of bioturbation and are predominantly composed of fragments of mollusk, foraminifera and Halimeda. The succession overlies Pleistocene reef limestone, which is usually altered diagenetically (Gischler, 2003).

The Belize Barrier Reef is $250 \mathrm{~km}$ long and forms the margin of the Belize shelf, which deepens from about $5 \mathrm{~m}$ in the north to some $50 \mathrm{~m}$ in the south (Figure 1). Surface sediments include reefal coralgal grainstones and Halimeda-rich wackestones and packstones in the back reef areas. Mollusk marls and siliciclastic sands are found on the southern shelf and nearshore areas, whereas mollusks, foraminifera and micritized grains predominate on the northern shelf (Purdy \& Gischler, 2003). 
Rasdhoo and Ari atolls are located in the western chain of the Maldives archipelago (Figure 1). Rasdhoo is a comparably small $\left(60 \mathrm{~km}^{2}\right)$ atoll with an almost continuous reef margin and a $40 \mathrm{~m}$ deep lagoon. Ari covers $2,300 \mathrm{~km}^{2}$, the reef margin is rather discontinuous with numerous tidal channels and the lagoon is as deep as $80 \mathrm{~m}$. Both lagoons contain patch reefs. Marginal and reefal sediments are coralgal grainstones. Lagoonal sediments are mollusk and foraminifera wackestone and packstones, as well as mudstone (Gischler, 2006). Mudstone occurs only in Rasdhoo lagoon and most common grains $>125 \mu \mathrm{m}$ are cemented fecal pellets.

The ramp offshore Kuwait deepens more or less continuously to some $30 \mathrm{~m}$ over a distance of $20 \mathrm{~km}$ (Figure 1). Isolated patch reefs occur in the inner and outer ramp. Facies belts run more or less parallel to bathymetric contours. They include nearshore ooid-skeletal grainstone and quartz sand, mid ramp mollusk grainstone and packstone, outer ramp mollusk marl wackestone and coralgal grainstone at reefs (Gischler \& Lomando, 2005).

In all samples used during this study, carbonate mineralogy is predominated by aragonite, which usually ranges from $70-90 \%$. High magnesium calcite normally reaches $10-$ $20 \%$ and low-magnesium calcite <10\% (Gischler \& Lomando, 1999, 2005; Gischler, 2006).

\section{METHODS}

The $\delta^{13} \mathrm{C}$ and $\delta^{18} \mathrm{O}$ values were determined on a total of 559 surface sediment samples from modern carbonate areas. These include 326 samples from the Belize-Yucatan platforms, 102 samples from the Belize barrier reef and shelf, 38 samples from two Maldivian atolls and 93 samples from the Kuwait ramp. In addition, 69 carbonate particle endmembers (coral, mollusk, algae and echinoderm fragments; ooids and peloids) were analyzed with regard to $\mathrm{C}$ and $\mathrm{O}$ isotopes. From the Belize atolls, we also measured $\mathrm{C}$ and $\mathrm{O}$ isotopes along six Holocene lagoon cores totalling 139 samples. The extensive raw data are deposited in electronic form.

Samples were reduced with a sample splitter and ground with mortar and pestle. Ground samples were analyzed at the University of Frankfurt with a ThermoFinnigan MAT 
253 mass spectrometer using the Gas Bench II (Finnigan Inc.) and at the University of Miami using an automated carousel attached to a Finnigan-MAT 251 mass spectrometer. Isotopic data are corrected using the procedures of Craig (1957) modified for a triple collector mass spectrometer. Data are quoted relative to Vienna Pee Dee Belemnite (V-PDB) according to the conventional notation. The analytical error at both laboratories is approximately $0.1 \%$. Isotope data were compared to mineralogical composition, i.e., percentages of aragonite, high-magnesium calcite (HMC), low-magnesium calcite (LMC) determined using X-ray diffraction and to facies, i.e., amounts of constituent particles as quantified by point counting in thin-section.

\section{RESULTS}

\section{Belize-Yucatan Carbonate Platforms, Caribbean Sea}

Surface sediments

Carbon isotope values $\left(\delta^{13} \mathrm{C}\right)$ range from +1.0 to $+5.5 \%$ and oxygen isotopes $\left(\delta^{18} \mathrm{O}\right)$ from -2.3 to $0 \%$ (Figure 2). There are no isotopic differences between carbonate facies, i.e., it is not possible to delineate facies based on their $\delta^{13} \mathrm{C}$ and $\delta^{18} \mathrm{O}$ values. End members of constituent particles exhibit even wider ranges (Figure 3). As regards $\delta^{13} \mathrm{C}$, corals usually have the lowest values, whereas non-skeletal grains such as peloids and green calcareous algae such as Penicillus show the highest values.

There are only a few cases of statistically significant correlations between isotopes and abundance of carbonate grains (Tables 1-4). In the shallow and open platforms of Lighthouse and Chinchorro, there are negative correlations between $\delta^{13} \mathrm{C}, \delta^{18} \mathrm{O}$ and abundance of coral and coralline algal fragments. In Glovers and Turneffe, no significant correlations between isotopes and constituent grains exist. Significant correlations between $\delta^{13} \mathrm{C}, \delta^{18} \mathrm{O}$ and the fine grain-size fraction $(<125 \mu \mathrm{m})$ only exist in Lighthouse. Statistically significant correlations between $\delta^{13} \mathrm{C}, \delta^{18} \mathrm{O}$ and aragonite content only occur in Chinchorro. Correlations are positive. There are no significant correlations between isotopes and water depth. 


\section{Subsurface sediments}

In six cores, $\delta^{13} \mathrm{C}$ ranges from -0.2 to $+5.2 \%$ (Figure $4 a$ ). All cores show an upcore trend towards higher $\delta^{13} \mathrm{C}$ values. Very low values at core bases correlate with diagenetic alteration close to deposits of the meteoric realm (soil, altered reef limestone), which usually are characterized by light $\delta^{13} \mathrm{C}$ values (Allan and Matthews, 1977). Above the meteorically influenced zone, i.e., above $4 \mathrm{~m}$ depth, $\delta^{13} \mathrm{C}$ values of individual cores only fluctuate slightly, up to $1.2 \%$. The $\delta^{13} \mathrm{C}$ of cores L5 and G7 exhibit considerably higher values as compared to the other cores. These cores also have a high abundance of Halimeda (Gischler, 2003).

The values of $\delta^{18} \mathrm{O}$ range from -1.9 to $-0.6 \%$ (Figure $4 \mathrm{~b}$ ). As with $\delta^{13} \mathrm{C}$, there are mostly trends towards higher values upcore as a consequence of diagenesis, as discussed above. Also, cores L5 and G7 show higher values than observed in the other cores.

\section{Belize Barrier Reef, Caribbean Sea}

Within the barrier reef and shelf samples, $\delta^{13} \mathrm{C}$ values range from -1.5 to $+4.7 \%$. The $\delta^{18} \mathrm{O}$ values plot between -3.2 and $-0.8 \%$ (Figure 5 ). Like in the atoll samples, there is no clear separation of samples with regard to carbonate facies, however, non-skeletal grains are among the heaviest measured with regard to carbon isotopes.

A number of statistically significant correlations exist between carbon and oxygen isotopes and abundance of constituent grains such as coral, foraminifera, non-skeletal grains and Halimeda (Table 5). The $\delta^{18} \mathrm{O}$ values also correlate with the amount of the fine grain-size fraction and with water depth. The $\delta^{18} \mathrm{O}$ values also exhibit a statistically negative correlation with aragonite content.

\section{Rasdhoo and Ari Atolls, Maldives, Indian Ocean}

Stable isotope values range from +0.5 to $+3.2 \%$ for $\delta^{13} \mathrm{C}$ and from -2.9 to $-1.4 \%$ for $\delta^{18} \mathrm{O}$, respectively (Figure 6). It is not possible to distinguish facies based on isotope values. Only the mudstone facies samples plot in a relatively narrow field. 
In Rasdhoo Atoll, a number of significant correlations are seen between $\delta^{13} \mathrm{C}, \delta^{18} \mathrm{O}$ and the abundance of Halimeda, mollusk and foraminifera (Table 6). The $\delta^{13} \mathrm{C}$ values also correlated with aragonite content and water depth. In Ari Atoll, no statistically significant correlations can be detected between $\delta^{13} \mathrm{C}, \delta^{18} \mathrm{O}$, abundance of constituent particles, fines, aragonite content and water depth (Tab. 7).

\section{Kuwait Ramp, Arabian-Persian Gulf}

Among surface sediment samples and constituent particle end members, $\delta^{13} \mathrm{C}$ values range from 0 to $+4.5 \%$ and $\delta^{18} \mathrm{O}$ from -2.1 to $+1.5 \%$ (Figure 7 ). Unlike in the barrier reef, atoll and platform examples, carbonate facies have characteristic isotope compositions.

There are statistically significant correlations between $\delta^{13} \mathrm{C}, \delta^{18} \mathrm{O}$ and the abundances of almost all constituent particles, with the fine grain-size fraction and with aragonite content (Table 8 ). $\delta^{13} \mathrm{C}$ is also statistically correlated with water depth.

\section{DISCUSSION}

\section{Patterns and comparisons}

Whereas the range of bulk $\delta^{13} \mathrm{C}$ (ca. +1 to $+5 \%$ ) is comparable among the sites studied, bulk $\delta^{18} \mathrm{O}$ values (range ca. -3 to $+2.3 \%$ ) show considerable differences in individual sites. In the Belize Barrier Reef and Maldive atoll samples, values are in the same range. Belize-Yucatan atoll samples show slightly heavier values and Kuwait ramp samples even more positive values. One possible explanation for these differences might be salinity, which is normal marine in the Maldives (around 35\%), normal marine to hyposaline (30-35\%o) on the Belize shelf (Purdy et al., 1975), elevated (35-42\%) in Belize-Yucatan atoll lagoons (Gischler et al. 2003) and hypersaline (39-43\%) on the Kuwait ramp (Gischler \& Lomando, 2005).

For comparison, Weber (1967) and Weber \& Woodhead (1969) measured ranges in $\delta^{13} \mathrm{C}$ of bulk carbonate sediments of +1.6 to $+4.5 \%$ and +0.75 to $+3.2 \%$ in Bermuda and on Heron Reef of Australia, respectively. The $\delta^{18} \mathrm{O}$ values from these settings ranged from -0.6 to $+0.4 \%$ in Bermuda and from -2.1 to $-0.4 \%$ on Heron Reef. Land (1989) compiled isotope 
data of shallow marine carbonate sediments. His values range from about -3.5 to $+5 \%$ for $\delta^{13} \mathrm{C}$ and from -3.5 to $+2 \%$ for $\delta^{18} \mathrm{O}$.

The $\delta^{13} \mathrm{C}$ and $\delta^{18} \mathrm{O}$ values of constituent carbonate sediment particles such as corals, algae, mollusks, foraminifera and others from the Belize and Kuwait locations exhibit even larger variations as compared to the bulk samples. Land (1989) came to a similar result, which can simply be explained by the fact that extreme isotope values may cancel each other out in a mixture of grain types (see, for example, Figure 7). Corals usually show the most negative values, whereas non-skeletal grains such as peloids and ooids and calcareous algae are isotopically heaviest. Variation within skeletal grain groups may be explained by taxonomic differences in isotopic fractionation and also by seasonal isotopic variation within skeletons (Emiliani et al., 1978; Wefer \& Berger, 1991). As a consequence of the latter observation, small fragments of skeletons may not necessarily yield representative $\delta^{13} \mathrm{C}$ and $\delta^{18} \mathrm{O}$ signals.

Spatial trends in isotopic composition of bulk samples are visible in the Kuwait ramp example in that carbon isotopes decrease from nearshore to offshore. In the atoll, barrier reef and platform examples, however, no clear trends are discernible. In Glovers, Lighthouse and Chinchorro, $\delta^{13} \mathrm{C}$ decreases from the platform interiors to margins. In the Belize Barrier Reef transects $1,3,5$ and $B$ there is an offshore increase in $\delta^{13} \mathrm{C}$, however, in transects 4 and $A$, there is an offshore decrease.

Likewise, carbonate facies could be characterized by their $\delta^{13} \mathrm{C}$ and $\delta^{18} \mathrm{O}$ composition in the ramp example, but not in the other locations. Statistical analyses show that there are also more significant correlations between isotope composition and carbonate mineralogy, abundance of grain types or facies on the Kuwait ramp. Also, all measured parameters including $\delta^{13} \mathrm{C}$ and $\delta^{18} \mathrm{O}$ values correlate statistically significant with water depth, i.e., with depositional energy on the ramp example. This difference is probably a consequence of the fact that the continuous depositional energy gradient on the Kuwait ramp largely controls carbonate facies. In the atoll, barrier reef and platform examples, depositional energy gradients are more variable and morphological and environmental variability is much higher. 
Several workers have found significant positive correlations between $\delta^{13} \mathrm{C}$ and the concentration of aragonite at carbonate platforms from numerous locations such as the Bahamas (Weber, 1967; Swart and Eberli, 2005; Swart et al., this volume), Australia (Weber and Woodhead, 1972) and the NW Australian shelf (Dix et al., 2005). In our study, such a correlation was only present in Chinchorro platform, Rasdhoo Atoll and the Kuwait ramp, but not in the other examples studied. We suggest that the reason for this difference is the elevated content of isotopically heavy non-skeletal grains at these three locations. Among the Belize-Yucatan platforms, Chinchorro has $30 \%$ peloids on average as compared to ca. $10 \%$ in the other platform locations. In the Maldive examples, Rasdhoo Atoll sediments contain peloids in contrast to Ari Atoll. The Kuwait ramp is rich in non-skeletal grains such as ooids, peloids and aggregate grains, just like the above-mentioned example of Great Bahama Bank (Purdy, 1963; Swart \& Eberli, 2005; Swart et al., this volume).

\section{Taphonomic and diagenetic filters}

Our subsurface results from the Belize platforms show that major fluctuations of several permille in $\delta^{13} \mathrm{C}$ along individual Holocene sections are associated with meteoric alteration near the Pleistocene/Holocene hiatus. However, isotopic variation along individual cores above the meteorically influenced horizon were rather low $(<1.2 \%)$. Possible explanations for the latter observation include taphonomic processes such as bioturbation and early diagenetic effects.

Bioturbation by the burrowing shrimp Callianassa characterizes large parts of the lagoonal areas of the Belize platforms (Gischler \& Lomando, 1999). By building large and complex burrows in unconsolidated sediment, Callianassa is able to rework and mix sediment to depths of almost $1 \mathrm{~m}$ (Scoffin, 1992). We speculate that during this process, isotopic variability is apparently reduced, as seen in the bulk of modern sediments. The fossil record of callianassids (Thalassinidean shrimps) extends back to the Jurassic (Myrow, 1995) and Callianassa-type bioturbation is known from carbonate platforms as old as Cretaceous (Sanders, 2001). The trace fossil Thalassinoides is reported from sedimentary rocks as old 
as the Cambrian (Myrow, 1995). Other organisms observed in bioturbation in the modern environments studied here include mollusk bivalves, echinoderms, polychaetes and fish. The fossil record of bioturbation for some of these organism groups goes as far back as the late Proterozoic, however, in general the Paleozoic record is much more fragmentary as compared to the Meso-Cenozoic record (Bromley, 1990).

Early diagenetic effects are of importance for the isotope composition of Holocene lagoonal carbonate sediments studied as well, which are to a large part made up of the metastable minerals aragonite and HMC. A number of previous studies have shown SEM evidence of partial dissolution of carbonate grains such as Halimeda, foraminifera and coralline algae in modern Caribbean reef settings (Perry, 2000). Partial dissolution occurs preferentially in back reef or lagoonal settings, largely a result of the lowering of $\mathrm{pH}$ during organic matter oxidation. Sediment in Callinassa-rich settings is especially prone to dissolution (Sanders, 2001). There is also geochemical evidence of dissolution and reprecipitation of calcium carbonate in Holocene and modern platform sediments of Florida Bay (Burns \& Swart, 1992; Patterson \& Walter, 1994b). No major changes in mineralogy were observed, however, shifts in trace element (strontium, magnesium) and stable isotopes of carbon and oxygen were significant. Recrystallization of modern shallow water skeletal grains from calcareous algae and foraminifera is widespread (Reid \& Macintyre, 1998) and was demonstrated in the fine grain-size fraction of sediments of the Belize platforms (Gischler \& Zingeler, 2002). Few geochemical studies indicate a lowering of minor element content, e.g., strontium (Reid \& Macintyre, 1998; Gischler \& Zingeler, 2002), however, it is largely unknown as yet to which degree early recrystallization processes also modify the isotopic composition of these carbonate grains.

For pre-Holocene settings, late diagenetic effects in the meteoric and burial environment have to be considered as well. Processes described include dissolution and recrystallization, neomorphism, LMC precipitation and dolomitization. In addition, lagoonal carbonate sediment can possibly get compacted and eventually develop features indicative of pressure dissolution. These processes are discussed at length in textbooks and will not be 
treated in detail, because this study focusses on the Holocene. Melim et al. (2001) described a Neogene example based on the investigation of diagenesis in two cores in Great Bahama Bank.

\section{Significance for carbon isotope stratigraphy}

The application of $\delta^{13} \mathrm{C}$ for stratigraphic correlation purposes has been applied for about a decade to ancient shallow water carbonate settings of ramps and platforms spanning the time from the Precambrian to the Tertiary (Joachimski \& Buggisch, 1993; Jenkyns, 1995; Vahrenkamp, 1996; Ferreri et al., 1997; Mutti et al., 1997; Grötsch et al., 1998; Wissler et al., 2003; Saltzman et al., 2004). In these studies, $\delta^{13} \mathrm{C}$ ranges from about -1 to $+5 \%$ and individual stratigraphic sections show an absolute range from approximately $1 \%$ to $4 \%$. Only Valladares et al. (1996) reported a range of up to $8 \%$ for $\delta^{13} \mathrm{C}$ along investigated Cretaceous sections. Likewise, Cozzi et al. (2004) presented large $\delta^{13} \mathrm{C}$ ranges from -8 to $+3 \%$ in a Proterozoic ramp. However, the reported ranges in $\delta^{13} \mathrm{C}$ and $\delta^{18} \mathrm{O}$ from the large majority of fossil ramp and platform sections fall well within the field of isotopic variability as seen in this study and in previous studies of $\delta^{13} \mathrm{C}$ and $\delta^{18} \mathrm{O}$ of modern shallow water carbonate sediments (Weber, 1967; Weber \& Woodhead, 1969; Land, 1989). Following this line of argument, the isotopic variation along ancient rock sections, which is used for stratigraphic correlation, could easily be explained by changes in taxonomic composition within individual carbonateproducing organism groups or simply by facies shifts. Swart \& Eberli (2005) showed that basin to bank correlations in the Miocene to Holocene of the Bahamas using $\delta^{13} \mathrm{C}$ is possible. However, they also found that $\delta^{13} \mathrm{C}$ along their sediment cores did not correlate with the global signal of $\delta^{13} \mathrm{C}$. Compositional variation in periplatform settings was reported to be rather the expression of varying mixtures of carbonate grains produced on the platform top, which eventually are exported and mixed with pelagic carbonate. Similar processes were probably effective in the pre-Neogene, however, the abundance and isotopic compositions of ancient platform-dwelling, carbonate-producing organisms such as corals, calcareous 
sponges, mollusks, foraminifera and calcareous algae, were not investigated in the abovementioned bulk rock isotope studies.

In summary, a number of effects influence $\delta^{13} \mathrm{C}$ and $\delta^{18} \mathrm{O}$ values of shallow water carbonate sediments. As discussed above, these include taxonomic variation, diagenesis and the fact that the majority of grains are composed of metastable aragonite and HMC. Taphonomic effects such as bioturbation are of importance as seen in the investigated Holocene cores. Therefore, results of bulk analyses of $\delta^{13} \mathrm{C}$ and $\delta^{18} \mathrm{O}$ of shallow water carbonate settings should only be used very carefully and in combination with additional sedimentological and paleontological data for stratigraphic and paleoenvironmental interpretations. Still, because carbon isotope stratigraphy appears to work fairly well in the ancient, it can be speculated that taphonomy and diagenesis act as isotopic "filters", which level out isotopic variation seen in the modern time slice. These taphonomic and diagenetic filters, however, are only poorly defined and not quantified as yet.

\section{CONCLUSIONS}

- The variability of $\delta^{13} \mathrm{C}$ and $\delta^{18} \mathrm{O}$ values of sediments in modern and Holocene shallow water carbonate settings such as platforms, barrier reefs, atolls and ramps is high, i.e., there are absolute ranges of $6.9 \%$ for $\delta^{13} \mathrm{C}$ and $5.5 \%$ for $\delta^{18} \mathrm{O}$, respectively.

- Clear spatial trends in isotopic composition of sediments were found only in the ramp setting, where carbonate facies also have characteristic isotopic compositions.

- The strongest isotopic excursions along Holocene sections are caused by diagenesis near a subaerial exposure horizon.

- The much lower range of carbon and oxygen isotopes found in fossil shallow water carbonates, e.g., in isotope stratigraphy, are presumably a consequence of taphonomic and diagenetic processes, which decrease isotopic variability. 


\section{ACKNOWLEDGEMENTS}

We thank R. Gless, C. Schroeder, A. Saied and D. Harazim for help during sample preparation for stable isotope and Xray-diffraction analyses. J. Fiebig ran the Frankfurt mass spectrometer and R. Petschick the Frankfurt diffractometer. The thoughtful reviews by W. Patterson (Saskatoon) and S. Hesselbo (Oxford) improved the paper and are gratefully acknowledged.

\section{REFERENCES}

Allan, J.R. and Matthews, R.K. (1977) Carbon and oxygen isotopes as diagenetic and stratigraphic tools: surface and subsurface data, Barbados. Geology, 5, 16-20.

Broecker, W.S. (1982) Ocean chemistry during glacial time. Geochim. Cosmochim. Acta, 46, 1689-1705.

Bromley, R.G. (1990) Trace fossils. Biology and taphonomy. Unwin Hyman, London, 280 p.

Burns, S.J. and Swart, P.K. (1992) Diagenetic processes in Holocene carbonate sediments: Florida Bay mudbanks and islands. Sedimentology, 39, 285-304.

Cozzi, A., Allen, P.A. and Grotzinger, J.P. (2004) Understanding carbonate ramp dynamics using $\delta^{13} \mathrm{C}$ profiles: examples from the Neoproterozoic Buah Formation of Oman. Terra Nova, 16, 62-67.

Craig, H. (1957) Isotopic standards for carbon and oxygen and correlation factors for massspectrometric analysis of carbon dioxide. Geochim. Cosmochim. Acta, 12, 122.

Dix, G.R., James, N.P., Kyser, T.K., Bone, Y. and Collins, L.B. (2005) Genesis and dispersal of carbonate mud relative to late Quaternary sea-level change along a distally-steepened carbonate ramp (northwestern shelf, western Australia). J. Sed. Res., 75, 665-678.

Drzewiecki, P.A. and Simo, J.A. (1997) Carbonate platform drowning and oceanic anoxic events on a mid-Cretaceous carbonate platform, south-central Pyrenees, Spain. J. Sed. Res., 67, 698-714. 
Emiliani, C., Hudson, J.H., Shinn, E.A., George, R.Y. and Lidz, B. (1978) Oxygen and carbon isotopic growth record in a reef coral from the Florida Keys and a deep-sea coral from the Blake Plateau. Science, 202, 627-629.

Ferreri, V., Weissert, H., D'Argenio, B. and Buoncunto, F.P. (1997) Carbon isotope stratigraphy: a tool for basin to carbonate platform correlation. Terra Nova, 9, 57-61.

Gischler, E. (2003) Holocene lagoonal development in the isolated carbonate platforms of Belize. In: Late Quaternary reef development (Eds. P. Blanchon and L.F. Montaggioni). Sed. Geol., 159, 113-132.

Gischler, E. (2006) Sedimentation on Rasdhoo and Ari atolls, Maldives, Indian Ocean. Facies, 52, 341-360.

Gischler, E., Hauser, I., Heinrich, K. and Scheitel, U. (2003) Characterization of depositional environments in isolated carbonate platforms based on benthic foraminifera, Belize, Central America. Palaios, 18, 136-255.

Gischler, E. and Lomando, A.J. (1999) Recent sedimentary facies of isolated carbonate platforms, Belize-Yucatan system, Central America. J. Sed. Res., 69, 747-763.

Gischler. E. and Lomando, A.J. (2005) Offshore sedimentary facies of a modern carbonate ramp, Kuwait, northwestern Arabian-Persian Gulf. Facies, 50, 443-462.

Gischler, E. and Zingeler, D. (2002) The origin of carbonate mud in isolated carbonate platforms of Belize, Central America. Int. J. Earth Sci., 91, 1054-1070.

Grötsch, J., Billing, I. and Vahrenkamp, V. (1998) Carbon-isotope stratigraphy in shallowwater carbonates: implications for Cretaceous black-shale deposition. Sedimentology, 45, 623-634.

Immenhauser, A., Kenter, J.A.M., Ganssen, G., Bahamonde, J.R., Van Vliet, A. and Saher, M.H. (2002) Origin and significance of isotopic shifts in Pennsylvanian carbonates (Asturias, Spain). J. Sed. Res., 72, 82-94.

Immenhauser, A., Della Porta, G., Kenter, J.A.M. and Bahamonde, J.E. (2003) An alternative model for positive shifts in shallow-marine carbonate $\delta^{13} \mathrm{C}$ and $\delta^{18} \mathrm{O}$. Sedimentology, 50, 953-959. 
Jenkyns, H.C. (1995) Carbon-isotope stratigraphy and paleoceanographic significance of the lower Cretaceous shallow-water carbonates of Resolution Guyot, mid-Pacific mountains. Proc. Ocean Drilling Prog. Sci. Res. (Eds E.L. Winterer, W.W. Sager, J.V. Firth and J.M. Sinton), 143, 99-104.

Joachimski, M.M. and Buggisch, W. (1993) Anoxic events in the late Frasnian - causes of the Frasnian-Famennian faunal crisis? Geology, 21, 675-678.

Land, L.S. (1989) The carbon and oxygen isotopic chemistry of surficial Holocene shallow marine carbonate sediment and Quaternary limestone and dolomite. In: Handbook of Environmental Isotope Geochemistry (Eds P. Fritz and J.C. Fontes), vol. 3, pp. 191217, Elsevier, Amsterdam.

Melim, L.A., Swart, P.K. and Maliva, R.G. (2001) Meteoric and marine-burial diagenesis in the subsurface of Great Bahama Bank. In: Subsurface geology of a prograding carbonate platform margin (Ed. R.N. Ginsburg). SEPM Spec. Publ., 70, 137-161.

Mutti, M., Bernoulli, D. and Stille, P. (1997) Temperate carbonate platform drowning linked to Miocene oceanographic events: Maiella platform margin, Italy. Terra Nova, 9, 122125.

Myrow, P.M. (1995) Thalassinoides and the enigma of early Paleozoic open-framework burrow systems. Palaios, $10,58-74$.

Patterson, W.P. and Walter, L.M. (1994a) Depletion of ${ }^{13} \mathrm{C}$ in seawater $\sum \mathrm{CO}_{2}$ on modern carbonate platforms: significance for the carbon isotopic record of carbonates. Geology, 22, 885-888.

Patterson, W.P. and Walter, L.M. (1994b) Syndepositional diagenesis of modern platform carbonates: evidence from isotopic and minor element data. Geology, 22, 127-130.

Perry, C.T. (2000) Factors controlling sediment preservation on a north Jamaican fringing reef: a process-based approach to microfacies analysis. J. Sed. Res., 70, 633-648.

Purdy, E.G. (1963) Recent calcium carbonate facies of the Great Bahama Bank. 2. Sedimentary facies. J. Geol., 71, 472-497. 
Purdy, E.G. and Gischler, E. (2003) The Belize margin revisited. 1. Holocene marine facies. Int. J. Earth Sci., 92, 532-551.

Purdy, E.G., Pusey, W.C. and Wantland, K.F. (1975) Continental shelf of Belize - regional shelf attributes. Amer. Assoc. Petrol. Geol. Stud. Geol., 2, 1-52.

Reid, R.P. and Macintyre, I.G. (1998) Carbonate recrystallization in shallow marine environments: a widespread diagenetic process forming micritized grains. J. Sed. Res., 68, 928-946.

Saltzman, M.R., Groessens, E. and Zhuralev, A.V. (2004) Carbon cycle models based on extreme changes in $\delta^{13} \mathrm{C}$ : an example from the lower Mississippian. Palaeogeogr. Palaeoclimatol. Palaeoecol., 213, 359-377.

Sanders, D. (2001) Burrow-mediated carbonate dissolution in rudist biostromes (Aurisina, Italy): implications for taphonomy in tropical, shallow subtidal environments. Paleogeogr. Palaeoclimatol. Palaeoecol., 168, 39-74.

Scholle, P.A. and Arthur, M.A. (1980) Carbon isotopic fluctuations in pelagic limestones: potential stratigraphic and petroleum exploration tool. Amer. Assoc. Petrol. Geol. Bull., 64, 67-87.

Scoffin, T.P. (1992) Taphonomy of coral reefs: a review. Coral Reefs, 11, 57-77.

Swart, P.K. and Eberli, G.P. (2005) The nature of the $\delta^{13} \mathrm{C}$ of periplatform sediments: implications for stratigraphy and the global carbon cycle. Sed. Geol., 175, 115-130.

Swart, P.K. , Reijmer, J.J. and Otto, R. (this volume) A Reevaluation of facies on Great Bahama Bank II: Variations in the $\delta^{13} \mathrm{C}, \delta^{18} \mathrm{O}$ and mineralogy of surface sediments. In: Perspectives in Sedimentary Geology: A Tribute to the Career of Robert Nathan Ginsburg, IAS Special Publication (Eds P.K. Swart, G.P. Eberli and J.A. McKenzie), In Press. Blackwell, Oxford.

Vahrenkamp, V.C. (1996) Carbon isotope stratigraphy of the upper Kharaib and Shuaiba Formations: implications for the early Cretaceous evolution of the Arabian Gulf region. Amer. Assoc. Petrol. Geol. Bull., 80, 647-662. 
Valladares, I., Recio, C. and Lendinez, A. (1996) Sequence stratigraphy and stable isotopes $\left(\delta^{13} \mathrm{C}, \delta^{18} \mathrm{O}\right)$ of the late Cretaceous carbonate ramp of the western margin of the Iberian chain (Soria, Spain). Sed. Geol., 105, 11-28.

Weber, J.N. (1967) Factors affecting the carbon and oxygen isotopic composition of marine carbonate sediments - Part I, Bermuda. Amer. J. Sci., 265, 586-608.

Weber, J.N. and Woodhead, P.M.J. (1969) Factors affecting the carbon and oxygen isotopic composition of marine carbonate sediments - II. Heron Island, Great Barrier Reef, Australia. Geochim. Cosmochim. Acta, 33, 19-38.

Wefer, G. and Berger, W.H. (1991) Isotope paleontology: growth and composition of extant calcareous species. Mar. Geol., 100, 207-248.

Weissert, H. (1989) C-isotope stratigraphy, a monitor of paleoenvironmental change: a case study from the early Cretaceous. Surv. Geophys., 10, 1-61.

Wissler, L., Funk, H. and Weissert, H. (2003) Response of early Cretaceous carbonate platforms to changes in atmospheric carbon dioxide levels. Palaeogeogr. Palaeoclimatol. Palaeoecol., 200, 187-205. 


\section{Figure captions}

Figure 1. (a) Locations of samples analyzed. (b) Map of the Belize-Yucatan area with carbonate platforms Glovers, Lighthouse, Turneffe (Belize) and Chinchorro (Mexico), as well as Belize Barrier Reef. For individual sample locations on platforms see Gischler and Lomando (1999). Barrier reef sample traverses indicated by black lines. Platforms and barrier reef are bathymetrically bounded by $200 \mathrm{~m}$ contour. (c) Maldive archipelago. For location of individual sample points see Gischler (2006). (d) Kuwait ramp area. For individual sample locations see Gischler and Lomando (2005).

Figure 2. C-O-isotope plot of sediments from Belize-Yucatan platforms. Note the overlap of isotopic composition of different facies.

Figure 3. C-O-isotopes of end members, Belize-Yucatan platforms. Isotopic variation is larger as compared to variation in bulk samples.

Figure 4. C-O-isotopes of sediments along Holocene lagoon cores, Belize platforms. Basal

${ }^{14} \mathrm{C}$-ages of carbonate sediments of individual cores are shown in the lower right corner. For location and description of cores see Gischler (2003).

Figure 5. C-O-isotope plot sediments from Belize Barrier Reef. Samples from different facire largely overlap with the exception of the non-skeletal facies.

Figure 6. C-O-isotope plot of sediments from Maldive atolls. Note the overlap of isotopic composition of facies.

Figure 7. C-O-isotope plot of sediments and end members from Kuwait ramp. Note relatively clear separartion of different facies and, larger isotopic range of constituent particles as compared to bulk samples. 


\section{Table captions}

Table 1. Correlation matrix of measured isotope values, mineralogy, water depth and abundance of constituent grains (Banco Chinchorro). Statistically significant correlations are marked bold $(p<0.05)$.

Table 2. Correlation matrix of measured isotope values, mineralogy, water depth and abundance of constituent grains (Lighthouse Reef). Statistically significant correlations are marked bold $(p<0.05)$.

Table 3. Correlation matrix of measured isotope values, mineralogy, water depth and abundance of constituent grains (Turneffe Islands). Statistically significant correlations are marked bold $(p<0.05)$.

Table 4. Correlation matrix of measured isotope values, mineralogy, water depth and abundance of constituent grains (Glovers Reef). Statistically significant correlations are marked bold $(p<0.05)$.

Table 5. Correlation matrix of measured isotope values, mineralogy, water depth and abundance of constituent grains (Belize Barrier Reef). Statistically significant correlations are marked bold $(p<0.05)$.

Table 6. Correlation matrix of measured isotope values, mineralogy, water depth and abundance of constituent grains (Rasdhoo Atoll). Statistically significant correlations are marked bold $(p<0.05)$

Table 7. Correlation matrix of measured isotope values, mineralogy, water depth and abundance of constituent grains (Ari Atoll). Statistically significant correlations are marked bold $(p<0.05)$.

Table 8. Correlation matrix of measured isotope values, mineralogy, water depth and abundance of constituent grains (Kuwait ramp). Statistically significant correlations are marked bold $(p<0.05)$. 


\section{Table captions}

Table 1. Correlation matrix of measured isotope values, mineralogy, water depth and abundance of constituent grains (Banco Chinchorro). Statistically significant correlations are marked bold $(p<0.05)$.

Table 2. Correlation matrix of measured isotope values, mineralogy, water depth and abundance of constituent grains (Lighthouse Reef). Statistically significant correlations are marked bold $(p<0.05)$.

Table 3. Correlation matrix of measured isotope values, mineralogy, water depth and abundance of constituent grains (Turneffe Islands). Statistically significant correlations are marked bold $(p<0.05)$.

Table 4. Correlation matrix of measured isotope values, mineralogy, water depth and abundance of constituent grains (Glovers Reef). Statistically significant correlations are marked bold $(p<0.05)$.

Table 5. Correlation matrix of measured isotope values, mineralogy, water depth and abundance of constituent grains (Belize Barrier Reef). Statistically significant correlations are marked bold $(p<0.05)$.

Table 6. Correlation matrix of measured isotope values, mineralogy, water depth and abundance of constituent grains (Rasdhoo Atoll). Statistically significant correlations are marked bold $(p<0.05)$

Table 7. Correlation matrix of measured isotope values, mineralogy, water depth and abundance of constituent grains (Ari Atoll). Statistically significant correlations are marked bold $(p<0.05)$.

Table 8. Correlation matrix of measured isotope values, mineralogy, water depth and abundance of constituent grains (Kuwait ramp). Statistically significant correlations are marked bold $(p<0.05)$. 


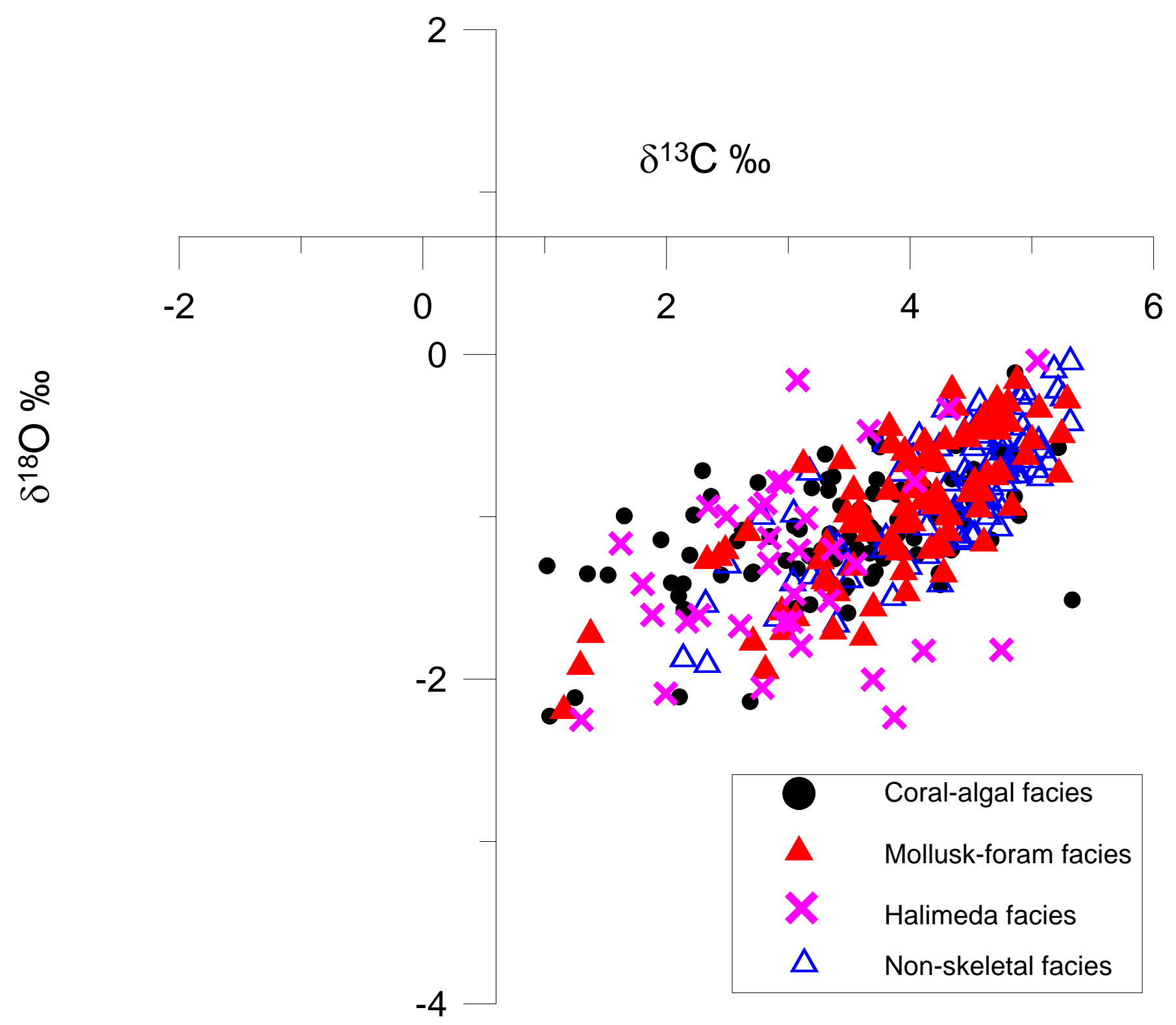

Figure 2 


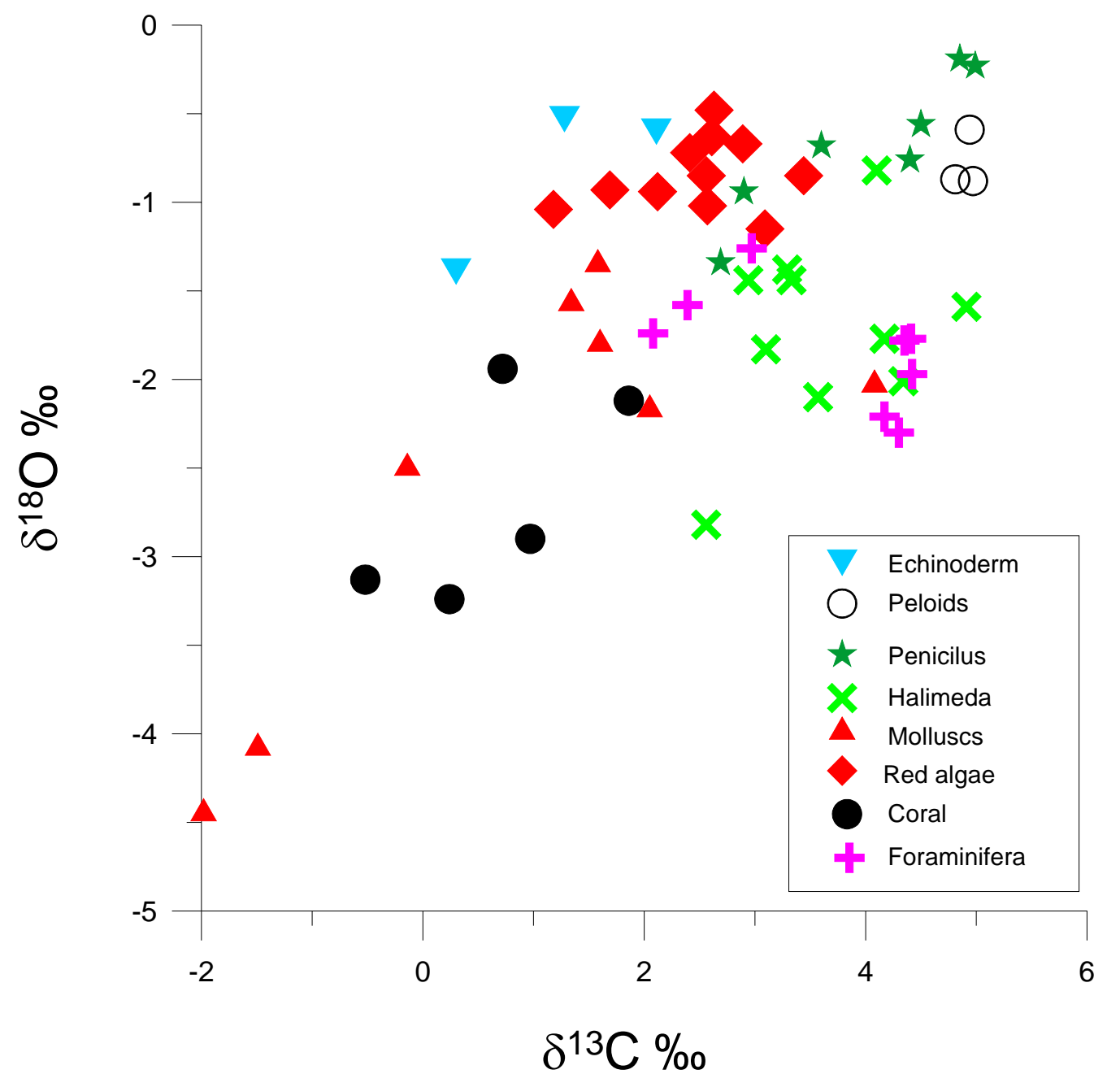

Figure 3 


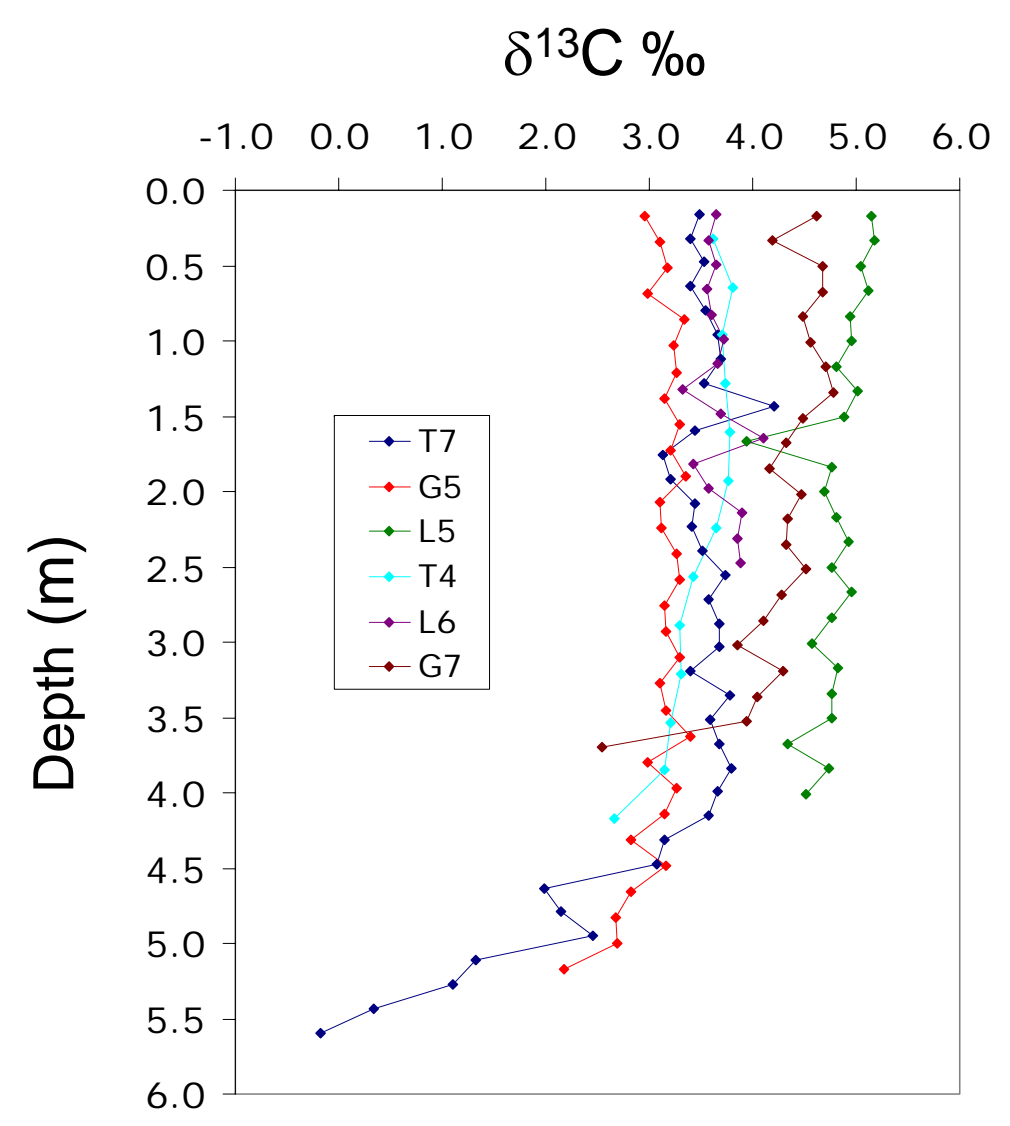

Figure $4 a$ 


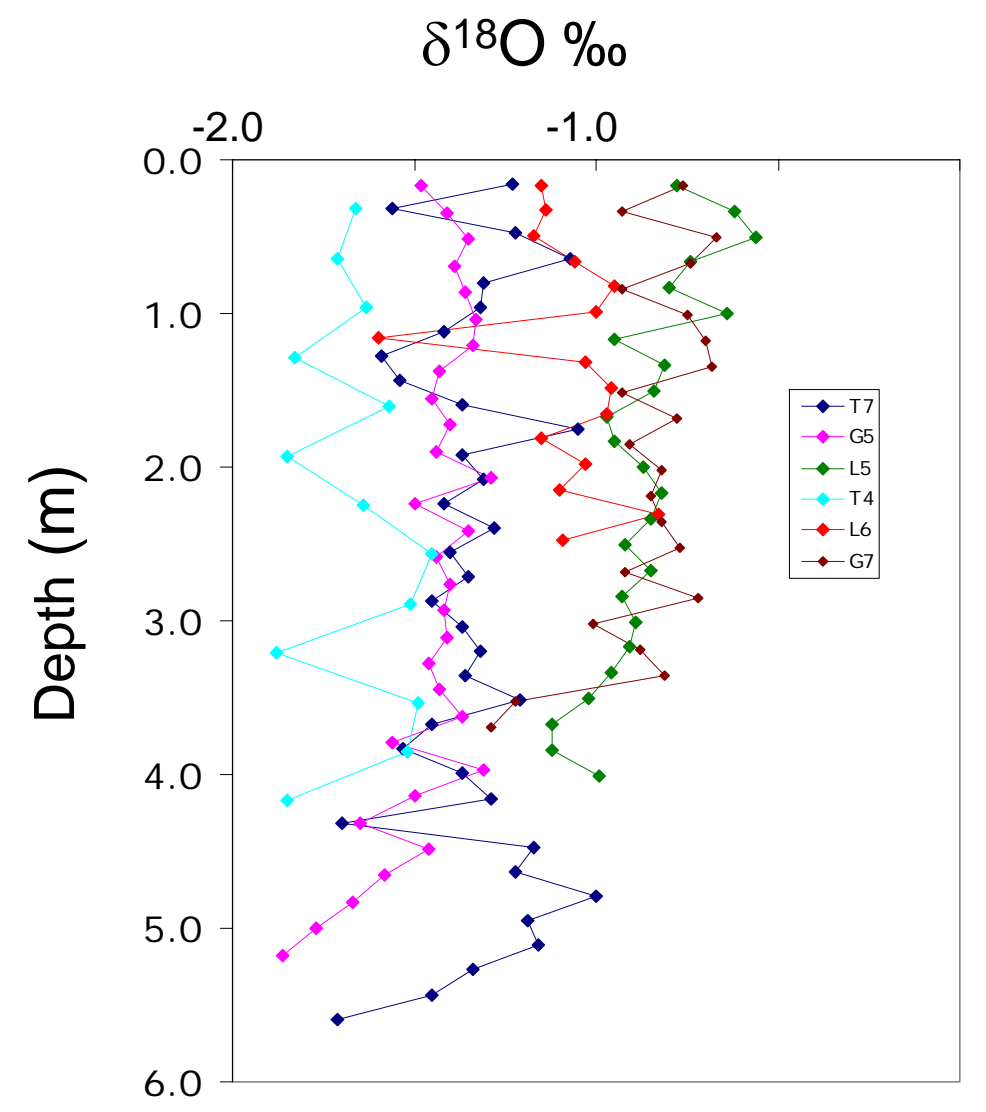

Figure $4 b$ 


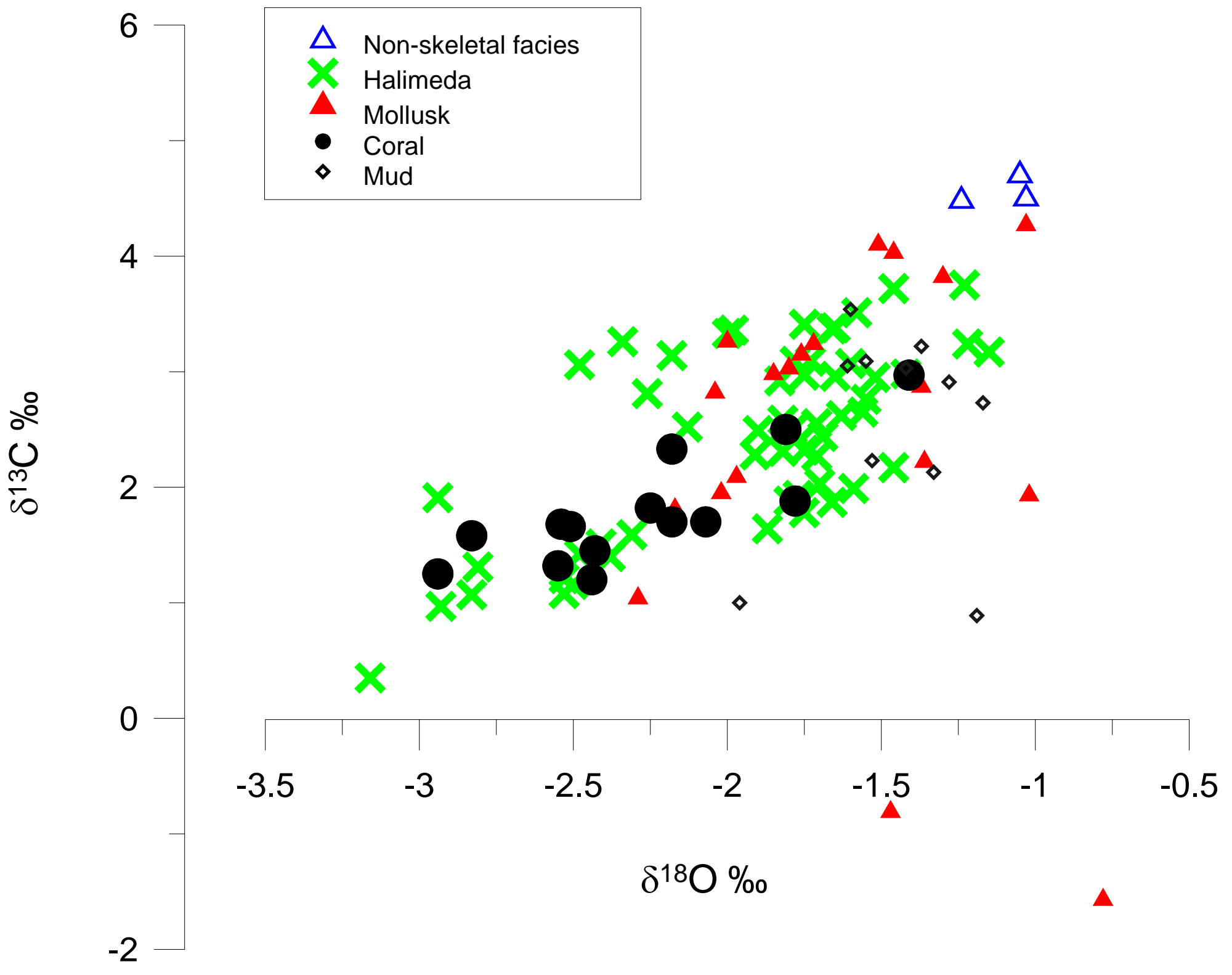

Figure 5 


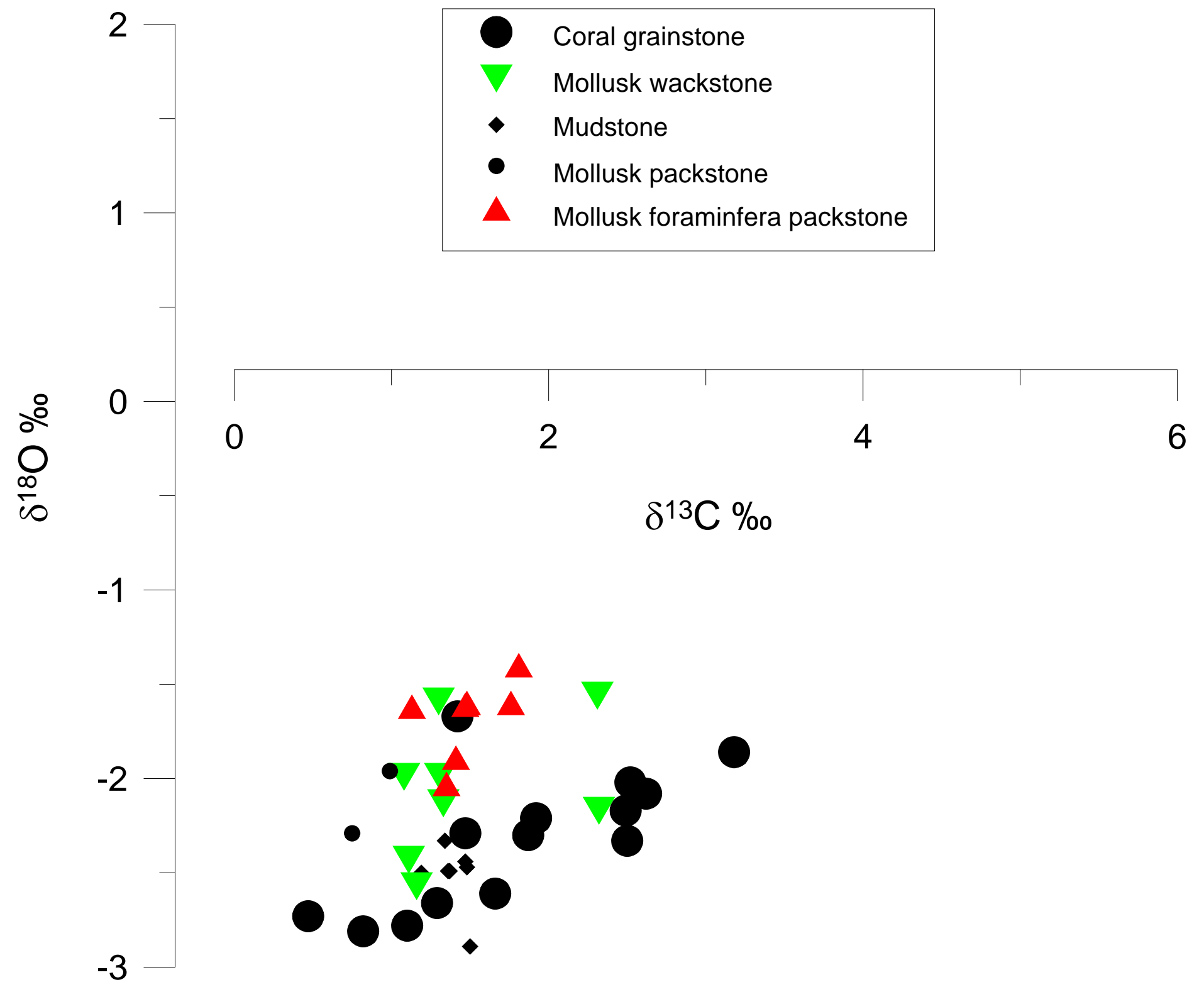

Figure 6 


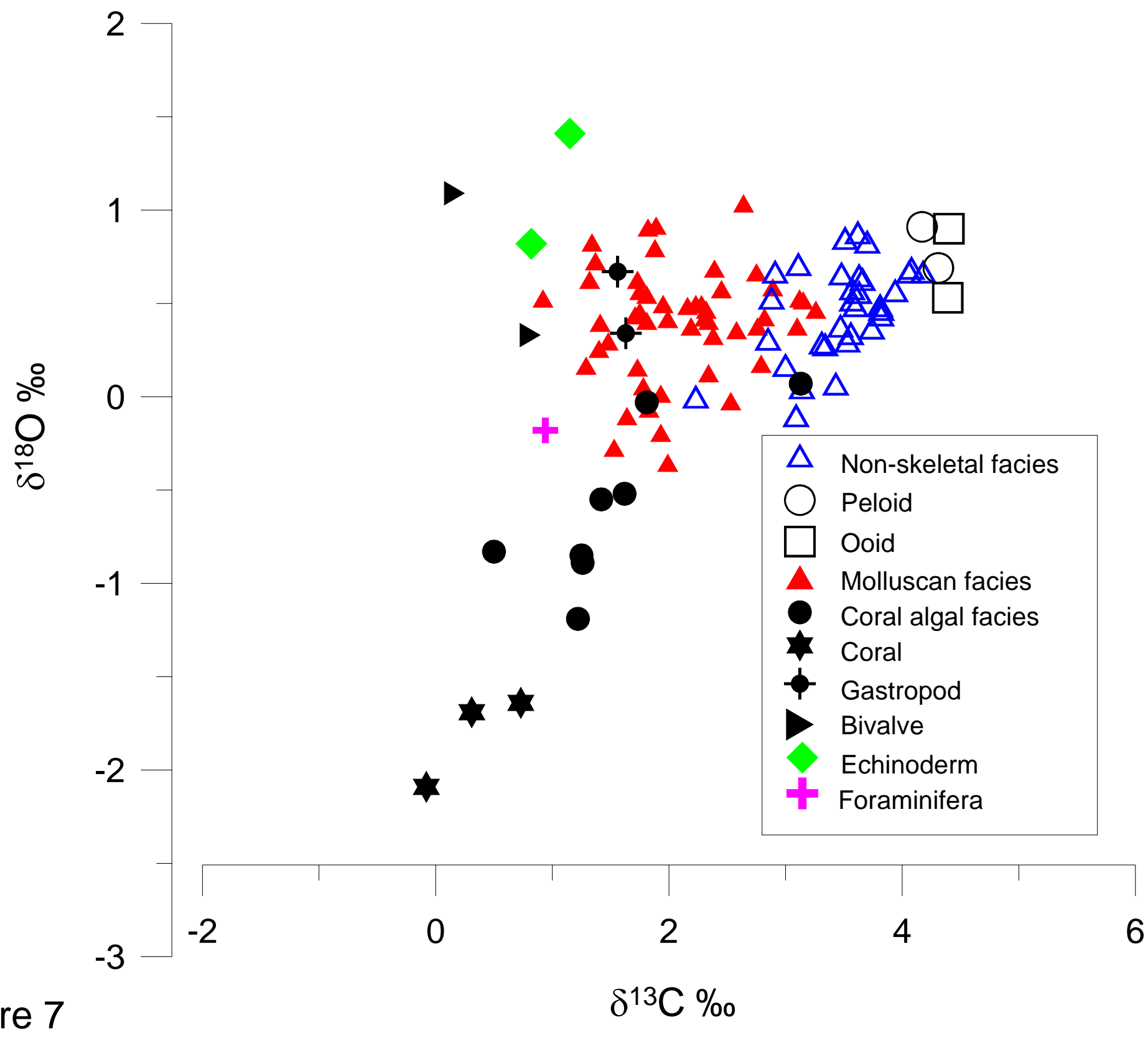


Table 1: Correlation matrix of Chinchorro data. Bold numbers indicate statistically significant correlation $(p<0.05)$.

\begin{tabular}{|c|c|c|c|c|c|c|c|c|c|c|}
\hline DEPTH & $\begin{array}{c}\text { DEPTH } \\
1\end{array}$ & MUD & HALIMEDA & CORAL & REDALGA & MOLLUSK & FORAM & NONSKEL & $\delta^{13} \mathrm{C}$ & $\delta^{18} O$ \\
\hline MUD & .576 & 1 & & & & & & & & \\
\hline HALIMEDA & -.327 & -.287 & 1 & & & & & & & \\
\hline CORAL & -.208 & -.283 & -.032 & 1 & & & & & & \\
\hline REDALGA & -.332 & -.299 & -.003 & .805 & 1 & & & & & \\
\hline MOLLUSK & .161 & .042 & .020 & -.261 & -.129 & 1 & & & & \\
\hline FORAM & .053 & .015 & .172 & -.341 & -.281 & .568 & 1 & & & \\
\hline NONSKEL & .038 & -.039 & -.429 & -.383 & -.404 & -.521 & -.524 & 1 & & \\
\hline$\delta^{13} \mathrm{C}$ & .145 & .020 & .093 & -.228 & -.267 & -.167 & .023 & .197 & 1 & \\
\hline$\delta^{18} O$ & .059 & .034 & .013 & -.233 & -.215 & -.188 & .157 & .166 & .740 & 1 \\
\hline ARA & -.015 & -.165 & -.014 & -.005 & -.052 & -.233 & -.067 & .212 & .605 & .424 \\
\hline
\end{tabular}


Table 2: Correlation matrix of Lighthouse data. Bold numbers indicate statistically significant correlation $(p<0.05)$.

\begin{tabular}{|c|c|c|c|c|c|c|c|c|c|c|c|}
\hline DEPTH & $\begin{array}{c}\text { DEPTH } \\
1\end{array}$ & MUD & HALIMEDA & CORAL & REDALGA & MOLLUSK & FORAM & NONSKEL & $\delta^{13} \mathrm{C}$ & $\delta^{18} O$ & ARA \\
\hline MUD & .274 & 1 & & & & & & & & & \\
\hline HALIMEDA & -.067 & -.482 & 1 & & & & & & & & \\
\hline CORAL & -.179 & -.693 & .068 & 1 & & & & & & & \\
\hline REDALGA & -.156 & -.745 & .291 & .839 & 1 & & & & & & \\
\hline MOLLUSK & .143 & -.141 & .091 & -.281 & -.198 & 1 & & & & & \\
\hline FORAM & .114 & -.027 & .257 & -.356 & -.160 & .474 & 1 & & & & \\
\hline NONSKEL & -.117 & .350 & -.531 & -.485 & -.585 & -.136 & -.241 & 1 & & & \\
\hline$\delta^{13} \mathrm{C}$ & -.098 & .409 & -.262 & -.482 & -.597 & .089 & .198 & .425 & 1 & & \\
\hline$\delta^{18} O$ & -.021 & .379 & -.306 & -.340 & -.428 & .088 & .219 & .232 & .540 & 1 & \\
\hline ARA & -.291 & -.542 & .339 & .414 & .327 & -.127 & -.177 & -.098 & -.107 & -.136 & 1 \\
\hline
\end{tabular}


Table 3: Correlation matrix of Turneffe data. Bold numbers indicate statistically significant correlation $(\mathrm{p}<0.05)$.

\begin{tabular}{|c|c|c|c|c|c|c|c|c|c|c|}
\hline DEPTH & $\begin{array}{c}\text { DEPTH } \\
1\end{array}$ & MUD & HALIMEDA & CORAL & REDALGA & MOLLUSK & FORAM & NONSKEL & $\delta^{13} \mathrm{C}$ & $\delta^{18} O$ \\
\hline MUD & -.030 & 1 & & & & & & & & \\
\hline HALIMEDA & .126 & -.348 & 1 & & & & & & & \\
\hline CORAL & -.090 & -.428 & -.508 & 1 & & & & & & \\
\hline REDALGA & -.090 & -.379 & -.482 & .750 & 1 & & & & & \\
\hline MOLLUSK & .078 & -.177 & .067 & -.342 & -.291 & 1 & & & & \\
\hline FORAM & -.007 & -.238 & -.062 & -.116 & -.088 & .241 & 1 & & & \\
\hline NONSKEL & -.015 & .099 & -.186 & -.089 & -.055 & -.072 & .049 & 1 & & \\
\hline$\delta^{13} \mathrm{C}$ & .011 & .091 & -.220 & .068 & .073 & -.034 & .122 & .130 & 1 & \\
\hline$\delta^{18} O$ & .021 & .054 & -.190 & .130 & .194 & -.106 & -.021 & .096 & .600 & 1 \\
\hline ARA & .081 & .032 & .486 & -.318 & -.468 & .060 & -.190 & -.170 & -.082 & -.086 \\
\hline
\end{tabular}


Table 4: Correlation matrix of Glovers Reef data. Bold numbers indicate statistically significant correlation $(p<0.05)$.

\begin{tabular}{|c|c|c|c|c|c|c|c|c|c|c|c|}
\hline DEPTH & $\begin{array}{c}\text { DEPTH } \\
1\end{array}$ & MUD & HALIMEDA & CORAL & REDALGA & MOLLUSK & FORAM & NONSKEL & $\delta^{13} \mathrm{C}$ & $\delta^{18} O$ & ARA \\
\hline MUD & .461 & 1 & & & & & & & & & \\
\hline HALIMEDA & -.310 & -.537 & 1 & & & & & & & & \\
\hline CORAL & -.402 & -.787 & .350 & 1 & & & & & & & \\
\hline REDALGA & -.355 & -.770 & .312 & .799 & 1 & & & & & & \\
\hline MOLLUSK & .251 & .159 & -.108 & -.512 & -.301 & 1 & & & & & \\
\hline FORAM & .230 & .253 & -.076 & -.475 & -.509 & .449 & 1 & & & & \\
\hline NONSKEL & -.014 & .056 & -.378 & -.389 & -.344 & .030 & .080 & 1 & & & \\
\hline$\delta^{13} \mathrm{C}$ & .064 & .249 & -.082 & -.165 & -.247 & -.037 & .129 & -.023 & 1 & & \\
\hline$\delta^{18} O$ & -.055 & .019 & .132 & -.039 & -.180 & -.012 & 156 & -.003 & .723 & 1 & \\
\hline ARA & .195 & .073 & -.042 & -.318 & -.222 & .339 & 199 & .262 & 172 & .154 & 1 \\
\hline
\end{tabular}


Table 5: Correlation matrix of Belize Barrier Reef data. Bold numbers indicate statistically significant correlation $(p<0.05)$.

\begin{tabular}{|c|c|c|c|c|c|c|c|c|c|c|}
\hline DEPTH & $\begin{array}{c}\text { DEPTH } \\
1\end{array}$ & ARA & $\delta^{18} O$ & $\delta^{13} \mathrm{C}$ & \multicolumn{2}{|c|}{ MOLLUSK HALIMEDA } & CORAL & REDALGA & NONSKEL & MUD \\
\hline ARA & .003 & 1 & & & & & & & & \\
\hline$\delta^{18} O$ & .214 & -.463 & 1 & & & & & & & \\
\hline$\delta^{13} \mathrm{C}$ & .112 & .123 & .463 & 1 & & & & & & \\
\hline MOLLUSK & -.117 & .123 & .026 & -.089 & 1 & & & & & \\
\hline HALIMEDA & -.089 & -.376 & .549 & .340 & .047 & 1 & & & & \\
\hline CORAL & .261 & .433 & -.205 & .065 & -.442 & -.397 & 1 & & & \\
\hline REDALGA & -.002 & .299 & -.533 & -.387 & -.112 & -.476 & -.015 & 1 & & \\
\hline NONSKEL & .069 & -.086 & .073 & -.057 & -.300 & -.154 & .181 & .322 & 1 & \\
\hline MUD & .040 & .232 & -.477 & -.480 & .099 & -.450 & .079 & .402 & .157 & 1 \\
\hline
\end{tabular}


Table 6: Correlation matrix of Rasdhoo Atoll data. Statistically significant correlations are marked bold $(p<0.05)$.

\begin{tabular}{|c|c|c|c|c|c|c|c|c|c|c|c|c|c|}
\hline DEPTH & $\begin{array}{c}\text { DEPTH } \\
1\end{array}$ & CORAL & REDALGA & HALIMEDA & MOLLUSK & FORAM & PELOID & AGGREG & ECHINO & MUD & $\delta^{13} \mathrm{C}$ & $\delta^{18} \mathrm{O}$ & ARA \\
\hline CORAL & -.843 & 1 & & & & & & & & & & & \\
\hline REDALGA & -.440 & .512 & 1 & & & & & & & & & & \\
\hline HALIMEDA & -.690 & .656 & .625 & 1 & & & & & & & & & \\
\hline MOLLUSK & .350 & -.253 & .330 & -.119 & 1 & & & & & & & & \\
\hline FORAM & .200 & .170 & .588 & .602 & .464 & 1 & & & & & & & \\
\hline PELOID & -.009 & -.147 & -.157 & -.218 & .131 & -.113 & 1 & & & & & & \\
\hline AGGREG & -.435 & .233 & .253 & .297 & .059 & .305 & .206 & 1 & & & & & \\
\hline ECHINO & .128 & .026 & .315 & -.081 & .604 & .231 & -.013 & -.056 & 1 & & & & \\
\hline MUD & .614 & -.730 & -.827 & -.750 & -.385 & -.660 & .066 & -.353 & -.352 & 1 & & & \\
\hline$\delta^{13} \mathrm{C}$ & -.562 & .296 & .333 & .782 & -.235 & .445 & .112 & .385 & -.381 & -.388 & 1 & & \\
\hline$\delta^{18} O$ & .120 & -.158 & .374 & .422 & .482 & .641 & .102 & .194 & .001 & -.374 & .591 & 1 & \\
\hline ARA & -.840 & .813 & .424 & .725 & -.460 & .232 & -.084 & .205 & -.128 & -.543 & .616 & .019 & 1 \\
\hline
\end{tabular}


Table 7: Correlation matrix of Ari Atoll data. Statistically significant correlations are marked bold $(p<0.05)$

\begin{tabular}{|c|c|c|c|c|c|c|c|c|c|c|c|c|c|}
\hline DEPTH & $\begin{array}{c}\text { DEPTH } \\
1\end{array}$ & CORAL & REDALGA & HALIMEDA & MOLLUSK & FORAM & PELOID & AGGREG & ECHINO & MUD & $\delta^{13} \mathrm{C}$ & $\delta^{18} O$ & ARA \\
\hline CORAL & -.748 & 1 & & & & & & & & & & & \\
\hline REDALGA & -.538 & .464 & 1 & & & & & & & & & & \\
\hline HALIMEDA & -.806 & .573 & .325 & 1 & & & & & & & & & \\
\hline MOLLUSK & .846 & -.798 & -.394 & -.631 & 1 & & & & & & & & \\
\hline FORAM & .585 & -.692 & -.068 & -.458 & .702 & 1 & & & & & & & \\
\hline PELOID & .406 & -.232 & -.154 & -.204 & .370 & .134 & 1 & & & & & & \\
\hline AGGREG & .388 & -.460 & .007 & -.306 & .443 & .817 & .012 & 1 & & & & & \\
\hline ECHINO & -.021 & -.219 & .003 & .040 & .285 & .195 & .009 & -.189 & 1 & & & & \\
\hline MUD & .434 & -.597 & -.641 & -.480 & .203 & -.055 & .036 & -.158 & -.056 & 1 & & & \\
\hline$\delta^{13} \mathrm{C}$ & -.091 & -.004 & -.158 & .395 & .141 & .189 & -.233 & .155 & .028 & -.321 & 1 & & \\
\hline$\delta^{18} O$ & -.021 & .082 & .372 & -.114 & -.022 & .060 & .022 & .024 & -.070 & -.163 & .162 & 1 & \\
\hline ARA & -.799 & .452 & .125 & .729 & -.712 & -.640 & -.161 & -.418 & -.072 & -.006 & .073 & -.118 & 1 \\
\hline
\end{tabular}


Table 8: Correlation matrix of Kuwait ramp data. Statistically significant correlations are marked bold $(p<0.05)$.

\begin{tabular}{|c|c|c|c|c|c|c|c|c|c|c|c|c|c|}
\hline MOLLUSK & $\begin{array}{c}\text { MOLLUSK } \\
1\end{array}$ & CORAL & REDALG & FORAM & OOID & PELOID & AGGREG & ECHINO & MUD & DEPTH & $\delta^{13} \mathrm{C}$ & $\delta^{18} O$ & ARA \\
\hline CORAL & -.498 & 1 & & & & & & & & & & & \\
\hline REDALG & -.427 & .873 & 1 & & & & & & & & & & \\
\hline FORAM & .290 & -.280 & -.272 & 1 & & & & & & & & & \\
\hline OOID & -.601 & -.151 & -.165 & -.118 & 1 & & & & & & & & \\
\hline PELOID & -.159 & -.318 & -.324 & -.104 & .234 & 1 & & & & & & & \\
\hline AGGREG & -.001 & -.210 & -.216 & -.341 & -.029 & .012 & 1 & & & & & & \\
\hline ECHINO & .245 & -.041 & .101 & .323 & -.312 & -.165 & -.262 & 1 & & & & & \\
\hline MUD & .088 & -.178 & -.177 & .303 & -.300 & -.068 & -.332 & .203 & 1 & & & & \\
\hline DEPTH & .692 & -.429 & -.332 & .358 & -.468 & -.256 & -.078 & .232 & .478 & 1 & & & \\
\hline$\delta^{13} \mathrm{C}$ & -.438 & -.292 & -.338 & -.334 & .739 & .536 & .274 & -.438 & -.317 & -.478 & 1 & & \\
\hline$\delta^{18} O$ & .264 & -.568 & -.510 & -.205 & .310 & .303 & .197 & -.333 & -.232 & .092 & .555 & 1 & \\
\hline ARA & -.288 & .031 & -.001 & -.654 & .413 & .325 & .317 & -.466 & -.527 & -.519 & .725 & .557 & 1 \\
\hline
\end{tabular}

